This is the final peer-reviewed accepted manuscript of

Lelli, Chiara; Bruun, Hans Henrik; Chiarucci, Alessandro; Donati, Davide; Frascaroli, Fabrizio; Fritz, Örjan;

Goldberg, Irina; Nascimbene, Juri; Tøttrup, Anders P.; Rahbek, Carsten; Heilmann-Clausen, Jacob:

Biodiversity response to forest structure and management: Comparing species richness, conservation relevant species and functional diversity as metrics in forest conservation: FOREST ECOLOGY AND

MANAGEMENT 432. ISSN 0378-1127

DOI: 10.1016/j.foreco.2018.09.057

The final published version is available online at:

http://dx.doi.org/10.1016/i.foreco.2018.09.057

Rights / License: The terms and conditions for the reuse of this version of the manuscript are specified in the publishing policy. For all terms of use and more information see the publisher's website. 


\title{
Biodiversity response to forest structure and management: Comparing species richness, conservation relevant species and functional diversity as metrics in forest conservation
}

\author{
Chiara Lelli $i^{\mathrm{a}, *}$, Hans Henrik Bruun ${ }^{\mathrm{b}}$, Alessandro Chiarucci ${ }^{\mathrm{a}}$, Davide Donati ${ }^{\mathrm{a}}$, Fabrizio Frascaroli ${ }^{\mathrm{a}}$, \\ Örjan Fritz ${ }^{\mathrm{c}}$, Irina Goldberg ${ }^{\mathrm{d}}$, Juri Nascimbene ${ }^{\mathrm{a}}$, Anders P. Tøttrup ${ }^{\mathrm{d}}$, Carsten Rahbek ${ }^{\mathrm{d}}$, \\ Jacob Heilmann-Clausen ${ }^{\mathrm{d}}$ \\ ${ }^{a}$ Department of Biological, Geological and Environmental Sciences, Alma Mater Studiorum University of Bologna, Via Irnerio 42, 40126 Bologna, Italy \\ b Department of Biology, University of Copenhagen, Universitetsparken 15, DK-2100 Copenhagen, Denmark \\ ${ }^{\mathrm{c}}$ Naturcentrum AB, Strandtorget 3, 44430 Stenungsund, Sweden \\ ${ }^{\mathrm{d}}$ Centre for Macroecology, Evolution and Climate, Natural History Museum of Denmark, University of Copenhagen, Universitetsparken 15, DK-2100 Copenhagen, \\ Denmark
}

A R T I C L E I N F O

Keywords:

European beech forests

Birds

Community-weighted mean

Epiphytes

GLMM

Habitat structure

Multi-taxon biodiversity

Rao's quadratic diversity

Vascular plants

Wood-inhabiting fungi

\begin{abstract}
A B S T R A C T
Aim: We investigated the consistency between richness and trait-based diversity metrics in capturing the effects of management-related habitat factors on biodiversity. The choice of biodiversity metrics can substantially affect the evaluation of conservation tools. However, the relative sensitivity of different metrics is not well investigated, especially in a multi-taxon framework.

Location: European beech forests in Denmark.

Methods: We studied 20 beech stands comprising four management types (from intensively managed to long unmanaged stands). We analyzed how management-related environmental variables were reflected in the measure of: (i) species richness, (ii) number of conservation-relevant species (red-listed species and old-growth forest indicators) and (iii) functional diversity targeting five organism groups with different habitat requirements, i.e. vascular plants, epiphytic lichens and bryophytes, saproxylic fungi and breeding birds.

Results: Plain species richness at stand level was generally misleading, as it did not capture changes in the number of conservation relevant species with changes in management-related environmental variables. The interpretation of functional responses was most informative for the better known vascular plants, while responses were more fragmented for the other organism groups. Overall, however, functional responses were consistent with a loss of specialization and progressive simplification of species assemblages from long-unmanaged to intensively managed stands.

Conclusions: Our findings suggest that the occurrence of conservation-relevant species is a sound and relevant metric for planning and evaluating conservation actions, especially for less studied organism groups (e.g., saproxylic fungi and epiphytes). The functional approach is promising, but presupposes the availability of databases of relevant traits.
\end{abstract}

\section{Introduction}

European beech forest is a fundamental type of natural vegetation in temperate Europe (Brunet et al., 2010). However, a long history of human use including modern forestry (Bengtsson et al., 2000) has led to substantial habitat loss and changes in forest structure and dynamics (e.g., Paillet et al., 2010; Burrascano et al., 2013). Human intervention has generated a simplification of forest ecosystems, with a consequent decrease of several sensitive and narrow range species depending on structures and processes of old growth forests (e.g., Brunet et al., 2010; Paillet et al., 2010, Sabatini et al., 2018). For instance, certain epiphytic bryophytes and lichens, which inhabit old and damaged trees, are threatened due to the removal of their habitat trees in production for ests (Fritz and Brunet, 2010). To counteract biodiversity loss, various measures have been suggested, spanning from the segregation of non intervention forest reserves to the integration of wildlife friendly

\footnotetext{
* Corresponding author.

E-mail address: chiara.lelli7@unibo.it (C. Lelli).
} 
elements, such as leaving retention trees and dead wood to support habitat specialists, in so called "near natural" forestry (Bauhus et al., 2009). While forest reserves represent a land sparing approach, "near natural" forestry is cognizant with a land sharing philosophy, resting on the assumption that silviculture can be optimized to protect most forest biodiversity without major consequences for economic outcomes. However, knowledge of the impacts of "near natural" forestry on biodiversity is limited in the temperate zone. Therefore it is debated how the two approaches can be combined and balanced to provide cost effective conservation (Kraus and Krumm, 2013).

So far, the effects of management on biodiversity have been investigated mostly with a focus on stand level species richness (Paillet et al., 2010; Chaudhary et al., 2016), probably because it represents the simplest way to measure biodiversity (Colwell and Coddington, 1994). Nevertheless, it presents relevant shortcomings. Firstly, species richness is highly prone to scale issues, which may result in misleading conclusions for conservation (Gotelli and Colwell, 2001; Chiarucci et al., 2011). In fact, fine scale partitioning of resources may generate patterns of species diversity not properly addressed if focusing only on one fixed spatial scale (e.g., Standovár et al., 2006). Further, high species richness within stands (i.e., alpha diversity) may mask lower levels of diversity across stands (i.e., beta diversity) with homogenization at regional level (i.e., gamma diversity) (Schall et al., 2018). Secondly, species richness may be misleading if adopted as an indicator for the conservation status of the forests. For instance, Boch et al. (2013) suggested species richness of vascular plants as indicator for dis turbance by management. Indeed, plants may benefit from resource increase (such as light or nutrients) following moderate disturbance by management or other human uses (Roberts, 2004; Christensen and Heilmann Clausen, 2009).

To account for these shortcomings, many researchers have focused on subsets of conservation relevant species (Dolman et al., 2012). Red listed species have been used to assess the conservation value of forests (Flensted et al., 2016), while other studies have focused on species with specific habitat requirements and/or particular biological attributes. For example, cavity nesting birds have been adopted as target species to indicate critical thresholds of veteran trees and microhabitat abundance (Winter and Möller, 2008). These target species are often associated with old growth forests conditions, including stand continuity (Hermy and Honnay, 1999; Schmidt et al., 2014). In many cases, however, the links between species and habitat conditions remain poorly understood or the bioindication is so obviously circular that the indicators have little relevance (Nordén et al., 2014; Halme et al., 2017).

Recently, functional approaches have been proposed as an alternative way to assess the impact of forest management on biodiversity (e.g., Giordani et al., 2012; Aubin et al., 2013). By focusing on the "kinds" of species rather than their numbers, a functional approach potentially gives a better understanding of the mechanisms driving habitat changes and species assemblages (Pausas and Verdú, 2010), allowing also comparisons across different ecosystems, regions and management systems. This approach may therefore be suitable to capture ecosystem properties and the effects of disturbances (e.g., Bässler et al., 2016a, 2016b). Despite these potentials, the reliability of functional measures is still not well known.

In all, choosing one metric of biodiversity over another may have substantial consequences on the evaluation of conservation tools. However, the consistency of different metrics is still scarcely investigated, especially in a multi taxon framework, limiting applicability in practice.

The aim of our study was to investigate if different metrics of diversity show consistent patterns along a management related environ mental gradient, from long unmanaged to even aged managed stands of European beech. We investigated how different diversity metrics (i.e., total species richness, richness of conservation relevant species, and functional diversity) were related to this gradient, and hence may be indicative for the variation of forest attributes (i.e., structural and environmental ones) across five organism groups (vascular plants, epiphytic lichens and bryophytes, saproxylic fungi and birds).

We expected a non consistency among the compared metrics, as well as among organism groups. Concerning the (1) total species richness (at stand level), we expected vascular plants to be favoured by human disturbance, in contrast to the other organism groups, but with a weak response of birds more likely depending on habitat suitability on a higher spatial scale than the stand level. Nevertheless, accounting only for the (2) richness of conservation relevant species we hypothesised a general decrease from the long unmanaged to the managed stands. Consistent with this trend we expected a homogenization of (3) functional diversity (at single trait level) for all the organism groups, with a trend towards more generalist strategies, broad ecological niches and higher dispersal ability as response of disturbance by management.

\section{Materials and methods}

\subsection{Study area}

The study was conducted in Gribskov, one of the largest coherent forests in Denmark, covering an area of almost 6.000 ha. The terrain is undulating (9 $89 \mathrm{~m}$ a.s.l.), with numerous boggy depressions. The topsoils are generally developed as mor or moder on glacial sandy to gravelly deposits stemming from the Weichelian glaciation. The forests are shaped by two centuries of timber oriented forestry, with European beech (Fagus sylvatica L.) and Norway spruce (Picea abies (L.) H. Karst.) dominating and largely found as even aged monocultures. European beech established in the area almost 6000 yrs ago, but became dominant only within the last 1000 yrs (Overballe Petersen et al., 2013), while Norway spruce was introduced with modern forestry during the latest 250 yrs (Rune, 2009). Only small remnants of old growth forests are left, mainly as stands smaller than 5 ha. The climate is temperate with an average annual precipitation of $697 \mathrm{~mm}$ and an annual mean temperature of $7.7^{\circ} \mathrm{C}$.

\subsection{Data collection}

Twenty forest stands, each 3 ha in size, were selected based on existing information and field visits during winter/spring 2015, using a stratified random sampling design to secure a balanced representation of management impact over space and time in the study landscape. The stands were selected to represent four broad classes based on man agement history and structural attributes in five replicates. Each class was defined based on detailed information in Graae and Buchwald (1997): (1) stands unmanaged for more than 50 years with dominant trees older than 200 years; (2) stands unmanaged for less than 50 years with dominant trees older than 100 years; (3) extensively managed biodiversity stands with dominant trees older than 100 years, and components of structural heterogeneity, in the form of a multi layered canopy and the presence of at least some coarse woody debris (CWD); and (4) intensively managed stands with dominant trees older than 100 years, a simple structure with one or two dominant tree layers and no or little CWD. All selected stands were dominated by European beech (> $60 \%$ of basal area). Due to the rarity of long unmanaged stands, these were selected first. In the second step, the topography, geography and general growth conditions (soil type) of the long un managed stands were used to guide the selection of stands in the other management categories, which were aggregated in four clusters con taining one or two replicates of each management type (Fig. 1). To account for random and non random spatial effects, we selected forest stands occurring in clusters where each of the four management levels is represented.

To sample the stands and collect species data, we randomly placed ten $50 \mathrm{~m}$ transects and ten circular plots with $5 \mathrm{~m}$ radius, respecting a minimum distance of $30 \mathrm{~m}$ between the plots. Up to five of the random plots were subsequently substituted with an equal number of plots 


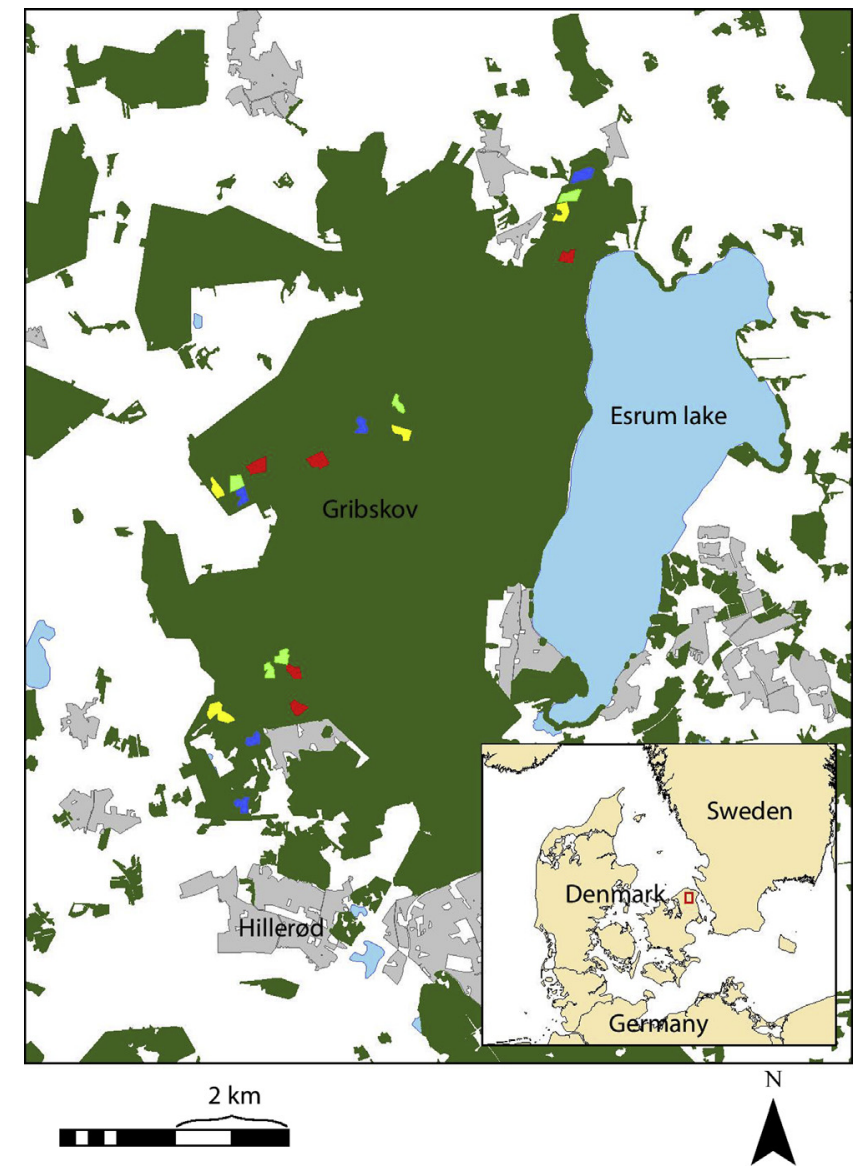

Fig. 1. Study area (Gribskov, Denmark). The forest stands along the gradient of management intensity are shown with different colours (blue = long-unmanaged, yellow $=$ recently unmanaged, red $=$ managed, light green $=$ nat. managed. In dark green the forest system including all the stands. (For interpretation of the references to colour in this figure legend, the reader is referred to the web version of this article.) strategically placed so as to best capture vegetation variations within each stand. Vascular plants were sampled on plots, while saproxylic fungi were sampled on transects. Epiphytes were investigated on ten trees within each stand, selected to maximize the occurrence of species of conservation concern. In each stand we identified potential host trees for epiphytes of conservation concern, i.e., focussing on old slow growing or damaged trees in contrast to healthy well growing trees (e.g., Fritz, 2009, 2011). Saproxylic macrofungi (including polypores, agarics, pileate corticioids, thick resupinate corticioids, i.e., species from the genera Coniophora, Phlebia and Steccherinum, larger dis comycetes and stromatic pyrenomycetes) were recorded on all sampled dead wood during two separate field visits (late Aug/early Sept and late Oct). At the latter sampling date, a stand level survey (maximum $1 \mathrm{hr}$ per stand) was conducted to record supplementary species. A quanti tative estimate of breeding birds was acquired by territory mapping (Bibby et al., 2000). The surveys were scheduled to span the breeding season of all potential breeding birds: end of April to end of June. The sites were visited in the early hours of the day, until around noon, where song activity is most intense. Days of rain and strong wind were generally avoided. Each study site was surveyed a total of 9 times. Each visit lasted around 45 min, depending on bird activity and local con ditions, and entailed both visual and auditory observations. On the basis of the completed set of field maps, final species maps were pro duced, quantifying the number of breeding bird territories for all ob served species. Territories that extended beyond the boundary of any given stand were counted as halves (Bibby et al., 2000).

The mapping of forest development phases was based on Emborg et al. (2000) with three amendments. First, the limit between early and late biostatic phase was set to a tree diameter of $70 \mathrm{~cm}$ DBH. Second, the degradation phase was expanded to embrace all situations where canopy cover was missing without regeneration being established. This included canopy gaps from tree felling in the shelterwood phase in managed stands, as well as natural canopy gaps with high grazing pressure and grassy vegetation. Third, wetlands with sufficiently high water table to hamper tree growth were mapped separately as wetlands.

Tree microhabitats were recorded based on a protocol modified from Winter and Möller (2008), differentiating ten main tree micro habitat types: (a) broken crown, (b) bark missing on trunk $>400 \mathrm{~cm}^{2}$,(c) bark loose on trunk $>400 \mathrm{~cm}^{2}$, (d) trunk cavities with entrance $>5 \mathrm{~cm}$ in diam., (e) trunk cavities with entrance $<5 \mathrm{~cm}$ in diam., (f)

Table 1

Description and survey methods for the structural variables used in the PCA ordination and for the organism groups. Levels: Stand (S); Plot (P); Transect (T); Ten European beech trees in each stand $(\mathrm{Tr})$.

\begin{tabular}{|c|c|c|c|}
\hline & Description & Level & Survey/source \\
\hline \multicolumn{4}{|l|}{ Structural variable } \\
\hline AGE & 2015 minus the establishment year of the (dominant trees of the) forest stand & $\mathrm{S}$ & State forest data from forestry maps \\
\hline IS & Innovation stage, with openings and presence of tree regeneration (saplings) & $\mathrm{S}$ & Mapped following Emborg et al. (2000) \\
\hline DS & $\begin{array}{l}\text { Degradation stage, with presence of gaps, undergrowth (herbs and shrubs) but } \\
\text { still not tree regeneration }\end{array}$ & $\mathrm{S}$ & $\begin{array}{l}\text { Mapped following Emborg et al. (2000) with amendments (see main } \\
\text { text) }\end{array}$ \\
\hline $\mathrm{W}$ & Presence of wetland sites too wet to sustain tree growth & $\mathrm{S}$ & \\
\hline MHT & Presence of microhabitats on trees with a DBH $>80 \mathrm{~cm}$ (veteran trees) & $\mathrm{T}$ & Mapped in a $10 \mathrm{~m}$ band along each transect \\
\hline $\mathrm{T}$ & Topography: range between the upper and the lower elevation (meters a.s.l.) & $\mathrm{S}$ & Extracted from GIS analysis of topographic maps \\
\hline $\mathrm{pH}$ & Average soil $\mathrm{pH}$ values & $\mathrm{P}$ & $\begin{array}{l}\text { Based on four replicate soil samples (excluding litter) in each plot } \\
\text { down to a depth of } 10 \mathrm{~cm}\end{array}$ \\
\hline pHR & Range of soil $\mathrm{pH}$ values & $\mathrm{P}$ & As above \\
\hline CWDF & Amount of fallen coarse woody debris (diam. $>10 \mathrm{~cm})$ & $\mathrm{T}$ & Sampled along each transect following Bate et al. (2009) \\
\hline FWD & Amount of fine woody debris (diam. $5-10 \mathrm{~cm})$ & $\mathrm{T}$ & $\begin{array}{l}\text { Sampled along the first } 10 \mathrm{~m} \text { of each transect following Bate et al. } \\
\text { (2009) }\end{array}$ \\
\hline CWDS & Amount of standing coarse woody debris (diam. $>10 \mathrm{~cm}$.) & $\mathrm{T}$ & Measured in a $10 \mathrm{~m}$ band along each transect \\
\hline STUMPS & total number of cut stumps & $\mathrm{T}$ & \\
\hline BA & Tree basal area (volume) - Living trees with DBH $>10 \mathrm{~cm}$ & $\mathrm{~T}$ & \\
\hline \multicolumn{4}{|l|}{ Organism groups } \\
\hline Vascular plants & $\begin{array}{l}\text { Vascular plants of the forest floor: herbs, shrubs, seedling and saplings of trees } \\
<2 \mathrm{~m} \text { tall }\end{array}$ & $\mathrm{P}$ & Presence/absence within each plot \\
\hline Epiphytes & Lichens and bryophytes & $\operatorname{Tr}$ & Presence/absence from the base of the trunk up to $2 \mathrm{~m}$ height. \\
\hline Saproxylic fungi & Fruit bodies of saproxylic macrofungi & $\mathrm{T}$ & Presence/absence on each recorded dead wood item \\
\hline Birds & Breeding pairs & S & Presence/absence per stand \\
\hline
\end{tabular}


pockets aggregating stagnant water or mould, ( $g$ ) fruit bodies of saproxylic fungi, (h) cankers, (i) wood pecker holes and (j) sap flow. The survey method adopted for each variable is summarized in Table 1.

\subsection{Functional traits}

Firstly, to investigate changes in functional diversity of each or ganism group as a response to management and other stand variables, we selected traits used in previous studies of forest biodiversity. To standardize as much as possible trait selection across groups, we considered how individual or species performance at a given site is determined by three main characteristics: acquisition, preservation and dispersion of resources over time (Garnier et al., 2016). Therefore, we first selected traits related to acquisition and preservation of resources and providing information about the structure of the assemblages. For vascular plants, we included the woodiness (Kleyer et al., 2008), which is informative of variations in the structural heterogeneity of assemblages. We classified epiphytic lichens by algal partner (photobiont type) and growth forms (Nimis and Martellos, 2017), as they are both related to assemblage structure and response to disturbance and forest structural changes (Giordani et al., 2012; Nascimbene and Marini, 2015). Bryophytes were classified into growth forms (During, 1992), which depend on abiotic environmental conditions, notably water resources and substrate affiliation (During, 1979, 1992). For fungi we included traits responsive to habitat changes (Nordén et al., 2013; Bässler et al., 2016b), related to fruit body size and type, and tree host preference (mainly based on Knudsen and Vesterholt, 2012; Ryvarden et al., 2014). Birds were classified according to body mass (Gotelli et al., 2010), dietary specialization (DOF, 2018), and nesting site (Svensson et al., 2010) and response to structural and environmental changes (Newbold et al., 2012).

Secondly, we compiled traits related to the dispersal potential within each organism group: reproductive strategy (Fitter and Peat, 1994) and dissemination vectors (Julve, 1998) for vascular plants (Graae and Sunde, 2000), main reproductive strategies (Nimis and Martellos, 2017) for lichens (e.g., Ellis, 2012; Giordani et al., 2012; Nascimbene et al., 2017), and dispersal vectors for saproxylic fungi responsive to forest structure and fragmentation (Heilmann Clausen et al., 2014; Bässler et al., 2016b).

Thirdly, as an attribute of ecological performance (Violle et al., 2007) we included Ellenberg indicator values for light (EIV, Ellenberg, 1974), available for vascular plants, lichens, bryophytes and fungi (Ellenberg et al., 1991; Hill et al., 2007; Wirth, 2010; Simmel et al., 2017). Indeed, light availability is an abiotic resource strongly influ enced by forestry operations.

Finally, as organisms' responses to environmental variability always involve a combination of traits, we included a classification of ecological strategies (Garnier et al., 2016) for plants and bryophytes. Life strategies for plants were drawn from Klotz et al. (2002) following Grime (2001). This three strategy model (CSR) is based on a set of traits matching different combinations of habitat favourability and disturbance. A life strategies classification for bryophytes was proposed by During (1979) based upon traits that often occur together and indicate disturbance tolerance (plants endure the stress period with their vegetative part) or avoidance (plants disappear leaving stress tolerant diaspores). All traits and attributes selected are listed in Table 2.

\subsection{Data analysis}

All analyses were conducted using stand level data, aggregated across sample trees (epiphytes), plots (vascular plants, soil pH, light conditions), transects (saproxylic fungi, variables related to living trees and dead wood), or the whole stand (birds, forest development phases, wetland areas). Our approach was to focus on the measured structural and environmental variables, rather than the four a priori defined management classes used in the selection of study sites. This choice was based on the observation that intermediate structural/environmental situations characterized many of the surveyed stands, which were thus better represented along gradients than as distinct categories.

Following the approach of previous studies (e.g., Bässler et al., 2016a) we applied principle component analysis (PCA) on the set of environmental and structural variables of each stand in order to reduce dimensionality of the complex conditions characterizing the study sites. We then used the scores of the first two PCA axes (henceforth, PC1 and PC2) as input variables to investigate biotic responses to changes in forest structure and environmental factors. We did not model the response of individual diversities to individual structural/environmental variables since our goal was to compare the response of the different organism groups (and sub groups within these), using the three diversity metrics, to common structural/environmental gradients. This approach also resulted in higher statistical power, since we could describe our environmental space using only two gradients. As an alter native to the PCA based classification we considered the option to use pre defined indexes to define the level of management impact (e.g., Gossner et al., 2014; Kahl and Bauhus, 2014), but this approach was disfavored due to the embedded subjective decisions involved in weighing the different primary metrics on which these are calculated.

We ran generalized linear mixed model GLMMs (Bolker et al., 2009) with the scores of PC1 and PC2 as fixed effects and with the four spatial clusters of forest stands as random effect. As response variables we used in turn: (i) species richness, (ii) richness of conservation relevant species, and (iii) functional diversity for each organism group. The models assumed (a) a Poisson distribution of errors for count data, (b) a Gaussian distribution of errors for continuous data, and (c) a Binomial distribution of errors for binary data and for frequencies.

(i) Total species richness was measured by counting the number of species occurring in each stand. The richness of (ii) conservation relevant species was calculated in the same way, considering a subset of species included in the Danish Red Lists (RL) (Wind and Pihl, 2004) and in lists of old growth indicators species, mostly considered associated with long temporal forest continuity (Nordén et al., 2013), based on Hermy and Honnay (1999) and Schmidt et al. (2014) for vascular plants, and Hallingbäck and Aronsson (1998), Thor and Arvidsson (1999), Nitare (2000) and Christensen et al. (2005) for bryophytes, lichens and wood inhabiting fungi. The supplementary species of saproxylic fungi were included in these counts.

(iii) Functional diversity was analysed by computing the community weighted mean (CWM) and Rao's quadratic entropy coefficient (RaoQ) at the single trait level, weighted by the frequency of each species at stand level (Ricotta and Moretti, 2011; Curzon et al., 2017). To measure the frequency, we counted in how many sampling units (plots/transects/ trees at stand level) each species was present. With the CWM, we measured shifts in mean trait values for each trait, expressing the central tendency for quantitative traits and the relative frequency of a given trait in a species assemblage for ordinal and nominal data (binary and dummy/fuzzy traits) (Garnier et al., 2004; Ricotta and Moretti, 2011). With the RaoQ index, we analysed patterns of trait convergence or divergence (i.e., a decrease or increase in trait dissim ilarity compared to a random expectation) (Mason et al., 2005; Lepš et al., 2006).

To compute CWM and RaoQ, we coded as ranks the ordinal data (e.g., EIV), while we expanded the nominal traits into binary data (e.g., woody/not woody) or dummy variables if more than two categories were present (e.g., growth forms). Nominal traits including categories with intermediate possibilities were coded as fuzzy variables (e.g., life forms) (Table 2).

All analyses were performed using $\mathrm{R}$ statistical software version 3.4.2 (R Core Team, 2017) with the packages "ade4" (Dray and Dufour, 2007), "factoextra" (Kassambara and Mundt, 2016), "lme4" (Bates et al., 2015) and "FD" (Laliberté et al., 2015). The "FD" package was

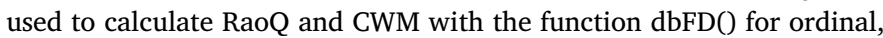
binary and quantitative data while the function functcomp() was used 
Table 2

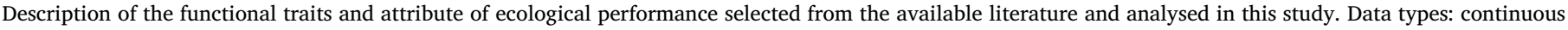
(quantitative) and categorical (binary, nominal, ordinal).

\begin{tabular}{|c|c|c|c|}
\hline Taxa & Trait & Data type & Range/categories \\
\hline \multirow[t]{5}{*}{ Vascular plants } & Woodiness & Binary & Woody, non-woody \\
\hline & Light indication & Ordinal & $1-9$ \\
\hline & Reproductive strategy & Nominal & Seeds and vegetative, Seeds \\
\hline & Dissemination vector & Nominal & Anemochory, Dyszoochory, Endozoochory, Epizoochory, Myrmecochory, Autochory, Barochory, Hydrochory \\
\hline & Life-strategy & Nominal (fuzzy) & Competitors, Stress-tolerators, Ruderals \\
\hline \multirow[t]{4}{*}{ Lichens } & Growth-forms & Nominal & Crustose, Foliose narrow-lobed, Foliose broad-lobed, Fruticose \\
\hline & Photobiont type & Binary & Chlorococcoid algae, Trentepohlia \\
\hline & Light indication & Ordinal & $1-9$ \\
\hline & Reproductive strategy & Nominal & Sexual reproduction, Sorediate species, Isidiate species \\
\hline \multirow[t]{4}{*}{ Bryophytes } & Growth-forms & Nominal & Cushions, Mats, Turfs, Others (Wefts, Tails, Dendroids: types with less than 5 species) \\
\hline & Light indication & Ordinal & $1-9$ \\
\hline & Substrate & Nominal & Epiphytic, Opportunistic, Terricolous \\
\hline & Life-strategies & Nominal & Colonist, Long-lived shuttle, Perennial \\
\hline \multirow[t]{7}{*}{ Fungi } & Fruit body size ${ }^{a}$ & Quantitative & $0-1$ \\
\hline & Fruit volume (Agaric) & & $20.5-244756.5 \mathrm{~mm}^{3}$ \\
\hline & Fruit thickness (Polypores) & & $1.5-250 \mathrm{~mm}$ \\
\hline & Fruit body type & Nominal & Agaric, Crustose, Polypore, Stroma, Others (types with less than 10 species) \\
\hline & Light indication & Ordinal & $1-9$ \\
\hline & Host preference & Nominal & Both (coniferous/deciduous), Coniferous, Deciduous, European beech (Fagus sylvatica L.) \\
\hline & Dispersal vectors & Binary & Asexual spores, Mycelial cords \\
\hline \multirow[t]{3}{*}{ Birds } & Body mass & Quantitative & $5.8-1200.5 \mathrm{~g}$ \\
\hline & Summer foraging guilds & Nominal & Omnivore, Herbivore (seeds and herbs), Insectivore, Prey \\
\hline & Nesting site & Nominal & Undergrowth, Trees, Tree hollows \\
\hline
\end{tabular}

${ }^{\text {a }}$ Fruit body size, normalized values of volume and thickness for the Agaric and Polypore types, respectively.

for nominal data coded as dummy or fuzzy variables. Functional traits for the vascular plants were retrieved from the "TR8" package (Bocci, 2015).

\section{Results}

The first principal component (PC1) of a PCA based on forest structural attributes accounted for $33.5 \%$ of the explained variation in the range of environmental predictors (Table 1) and captured a gradient in management related environmental variables, with long unmanaged stands clearly differentiated from stands in the three other stand classes (Fig. 2).

Presence of veteran trees and high basal area differentiated long unmanaged stands with low axis scores from intensively managed stands with high amounts of stumps and high axis scores (Fig. 3). The second component (PC2) accounted for $18.9 \%$ of the explained var iance and was mostly related to topography, canopy openness and soil productivity. Low axis scores were associated with high soil $\mathrm{pH}$ and presence of wetlands, while hilly topography and high light availability (forest openings) characterized stands with high axis scores (Fig. 3). The amount of coarse woody debris and stand age were correlated with both PC1 and PC2, with highest values in unmanaged stands on less rugged and more productive soils. The wide scatter of short unmanaged and extensively managed stands in the ordination space reflects that these are highly heterogeneous, reflecting differences in historical management.

A total number of 130 vascular plant species (mean $=36.8$, $\mathrm{SD}=9.3$ at stand level), 78 species of epiphytic lichens (mean $=29.6$, $\mathrm{SD}=8.2$ ), 29 species of epiphytic bryophytes (mean $=9.8, \mathrm{SD}=2.6$ ), 209 species of saproxylic fungi (mean $=54.4, \mathrm{SD}=11.2$ ), and 33 species of birds (mean $=16, \mathrm{SD}=2.6$ ) were recorded in the 20 stands. For 162 species of saproxylic fungi we calculated frequency data at stand level, since they were recorded along the ten transects of each stand. Only these species were included in the analyses of functional diversity. The remnant 47 species (supplementary species) were recorded in the last stand level survey, with only presence/absence annotation at stand level.
The (i) stand level species richness of vascular plants was positively correlated to PC1, while this relation was negative in the case of saproxylic fungi and epiphytic lichens. Similarly, stand level richness of epiphytic lichens was positively associated with PC2, while saproxylic fungi showed a significant negative relation with the same gradient (Table 3).

Concerning the (ii) conservation relevant species, red listed species were only recorded among lichens (42) and wood inhabiting fungi (15), and were negatively related to changes in management related environmental variables expressed by PC1 (Table 3). Fungi were negatively related also to the forest structural gradient expressed by PC2, while the relation of red listed species of lichens to this gradient was marginally positive (Table 3 ). The old growth indicator species of lichens (12 species), bryophytes (7), and saproxylic fungi (29 species) decreased with PC1 (Table 3), while vascular plant indicator species (32 species) showed a positive trend along the same gradient, using both lists in Hermy and Honnay (1999) and Schmidt et al. (2014). Negative relations with PC2 were found for vascular plants and saproxylic fungi (Table 3).

A relation of (iii) functional diversity, measured as functional divergence (RaoQ) and CWM, with PC1 was found to be significant especially for vascular plants (Table 4, Fig. 3), as the relative occurrence and functional divergence of woody species decreased from long unmanaged to managed stands along PC1. We also found an increasing similarity in reproductive strategies (i.e., increasing proportion of generalist species with both vegetative and sexual reproduction) and dissemination vectors, with an increasing occurrence of epizoochorous species, at higher axis values. Stress tolerators showed a near significant positive relation with the gradient, as opposed to competitive species. Among the other organism groups, cushion shaped epiphytic bryophytes had a positive relation with PC1, while there was a decrease of other growth forms (including wefts, tails, and dendroids). Species with higher EIV increased along PC1, together with an increasing trait divergence. Saproxylic fungi with a generalist preference for deciduous wood showed a positive relation with PC1, contrary to species with a species specific host preference for European beech (Fagus sylvatica L.).

Along the second axis (PC2, Table 2) we found an increasing 


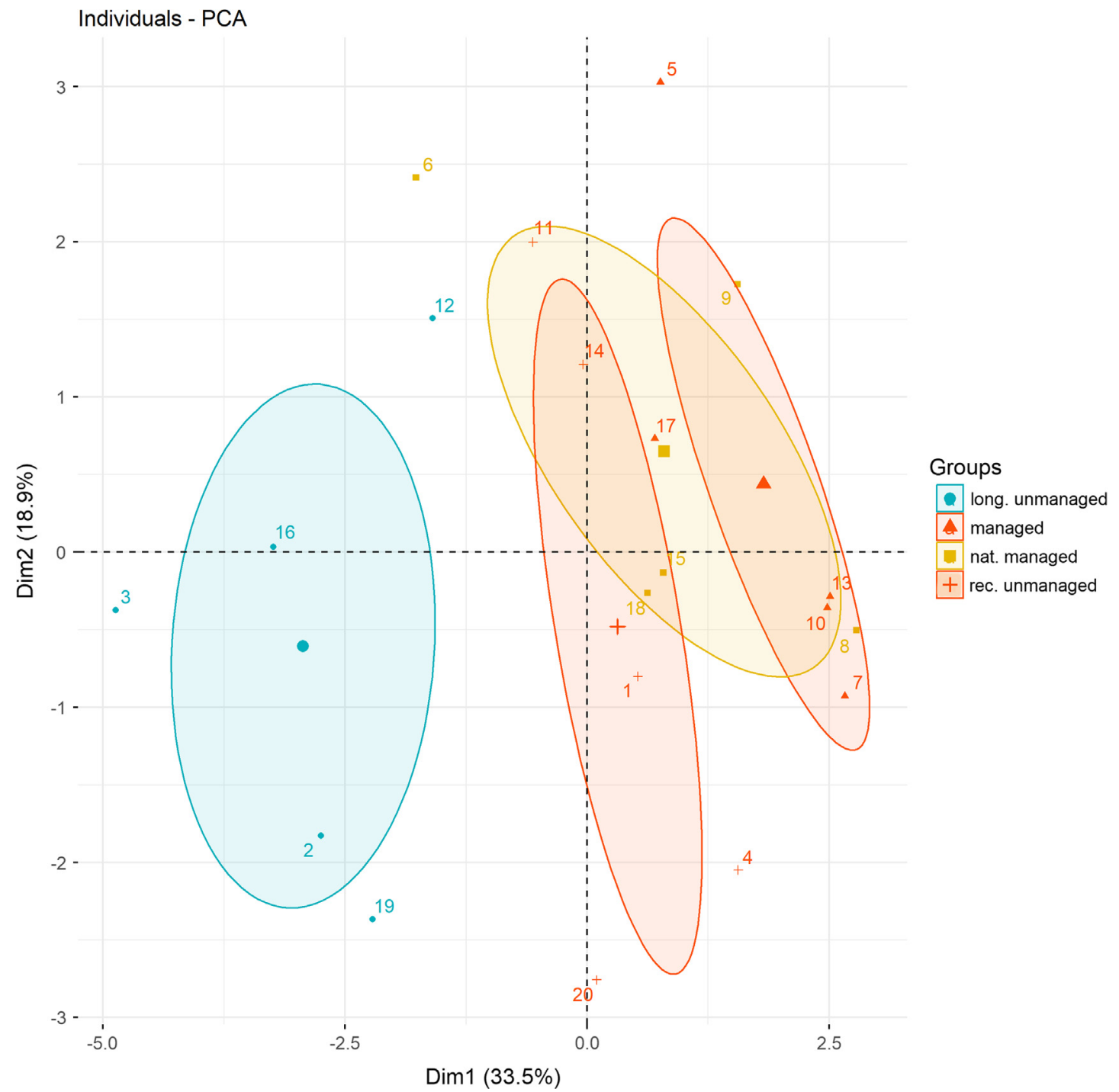

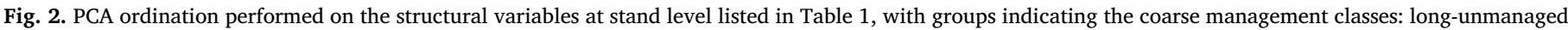

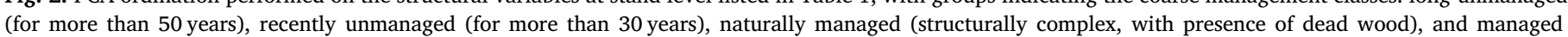

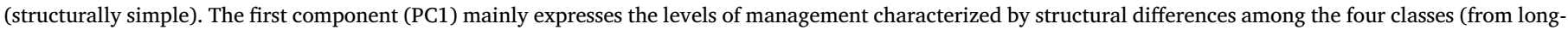

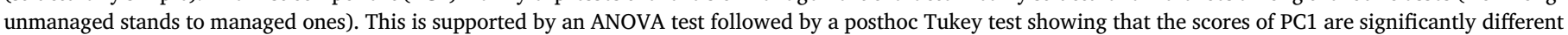
among the management classes, with especially a strong differentiation of the long unmanaged stands compared to the others.

occurrence of vascular plants with high EIV. Functional divergence in lichens growth forms also rose along PC2, accompanied by higher occurrence of foliose broad lobed species versus crustose species. The occurrence of lichens with an asexual reproduction was also positively related with PC2, while species with a sexual reproduction decreased. Regarding the bryophytes, the number of mat shape species declined along PC2, while turfs increased. Saproxylic fungi showed the same trend as described for PC1, with an increase in generalist substrate requirements and a decrease of host specialists.

\section{Discussion}

We found that simple species richness, versus a trait/"indicator" based approach showed inconsistent patterns along the structural and environmental gradients investigated in European beech forests.

The main findings are that (i) the measure of stand level species richness obscured changes in the number of (ii) conservation relevant species (old growth specialists and red listed species). The (iii) functional approach mostly captured variations in vascular plant assemblages from long unmanaged to intensively managed stands, while signals were less clear with regards to the other organism groups. Species richness of vascular plants (including old growth specialists) increased from long unmanaged to managed stands along PC1, showing an opposite trend compared to the other organism groups. However, the functional approach indicated that this increase was mainly due to establishment of species with generalist traits, in particular high dispersal potential and affiliation with disturbed habitats in general.

\subsection{Species richness}

Stand level species richness was weakly sensitive to changes in forest structure from long unmanaged to intensively managed stands, but with lack of congruent patterns across different organism groups, as also reported in other studies (e.g., Christensen and Heilmann Clausen, 2009; Paillet et al., 2010, Sitzia et al., 2017). In fact, only the richness of vascular plants showed an increase with changes in management related environmental variables from long unmanaged to managed stands, in contrast to the number of conservation relevant species of wood inhabiting fungi, epiphytic lichens and bryophytes. This strongly supports that species richness of vascular plants is poorly suited as a 


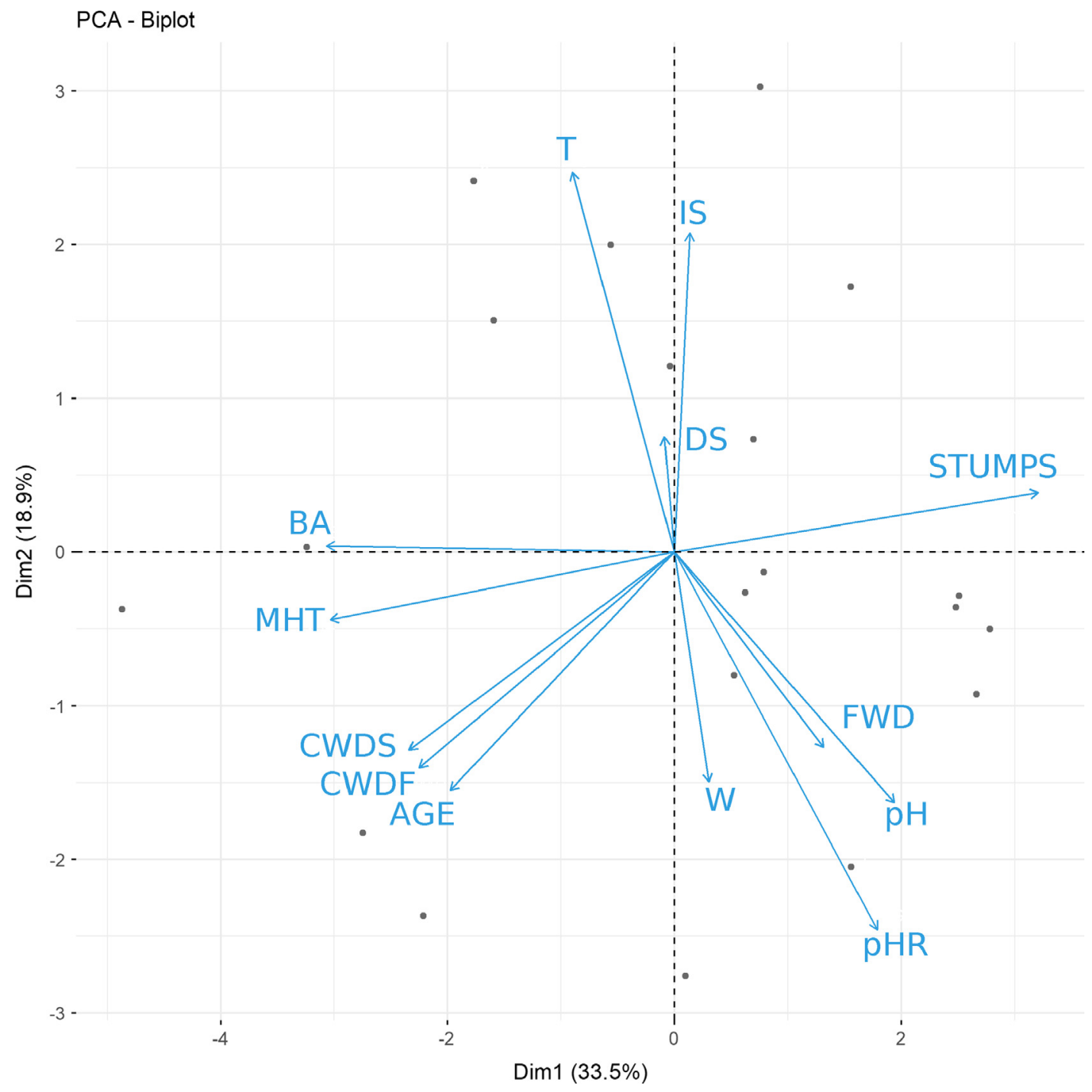

Fig. 3. PCA ordination performed on the structural variables at stand level in Table 1. The first axis (PC1) accounts for $33.5 \%$ of the explained variation in the range of environmental predictors, mainly expressing changes in management-related environmental variables from long-unmanaged to managed stands: the presence of veteran trees (MHT) and a high basal area (BA) differentiated long-unmanaged stands with low axis scores, while in the opposite direction high amounts of stumps characterizes the most intensively managed stands. The second axis (PCA2) accounts for $18.9 \%$ of the explained variance and represents a main gradient of site productivity/canopy openness across stands unrelated to management (an ANOVA test performed on the scores of PC2 vs the management classes indicates no significant differences among the classes). This gradient is mostly related to topography (T) (+), canopy openness (IS, DS) (+) and soil productivity ( - ): low axis scores are associated with high soil $\mathrm{pH}(\mathrm{pH}, \mathrm{pHR}$ ) and presence of wetlands (W), while hilly topography and high light availability (forest openings represented by the innovation and the degradation stages, IS, DS) characterized stands with high axis scores. The amount of dead wood (CWDS, CWDF) and stand age is correlated with both PC1 and 2, showing highest values in unmanaged stands on flatter and more productive soils.

Table 3

Results of GLMMs using species richness (SR), conservation relevant species (red-listed species RL and old-growth forest specialists OG) as response variables and scores of the first two PCA-axes as fixed effects (random effect: spatial clusters of stands). PCA ordination was performed on the structural variables in Table 1.

\begin{tabular}{|c|c|c|c|c|c|c|}
\hline \multirow[b]{2}{*}{ Organism group } & \multicolumn{3}{|l|}{ PC1 } & \multicolumn{3}{|l|}{ PC2 } \\
\hline & SR & RL & OG & SR & RL & OG \\
\hline Vascular plants & $+{ }^{* * 0 * k}$ & a & $+"$ & $\mathrm{~ns}$ & a & $-^{\circ}$ \\
\hline Lichens & $-{ }^{*}$ & $-{ }^{* * * *}$ & $-{ }^{* * *}$ & $t^{*}$ & $t^{\circ}$ & $\mathrm{ns}$ \\
\hline Bryophytes & $\mathrm{ns}$ & a & $--^{* * * *}$ & $\mathrm{~ns}$ & a & ns \\
\hline Fungi & $-{ }^{*}$ & $-{ }^{* * *}$ & -* & $-{ }^{* * * * *}$ & -* & $-{ }^{* * *+1}$ \\
\hline Birds & $\mathrm{ns}$ & a & a & $\mathrm{ns}$ & a & a \\
\hline
\end{tabular}

+ and - symbols denote positive or negative trend, respectively.

ns, not significant, ${ }^{\circ}$ p-value $<0.1,{ }^{*}$ p-value $<0.05,{ }^{* * *}$-values $<0.01$.

a, none of the sampled species listed as RL or OG. proxy indicator of conservation value for other groups of forest organisms, as also reported by Sabatini et al. (2016). Our results even question the relevance of stand level species richness among the other groups considered. Focusing on total species richness, without considering the number of conservation-relevant species, may lead to misleading conclusions for conservation purposes due to a non-consistency among the two metrics. For instance, we found that a nonsignificant variation in the species richness measured for the epiphytic bryophytes did not reflect a significant decrease of conservation-relevant species at changing management-related environmental variables.

Therefore, we argue that the richness of conservation-relevant species can be suited as indicator of management impact, but only for some organism groups (i.e., epiphytes and saproxylic fungi in our study) and in a well described context. According to the approach adopted in this study, we refer to management impact considering changes in management-related environmental variables (e.g., 
Table 4

Results of GLMMs using single-traits/attributes as response variables and scores of the first two PCA-axes as fixed effects (random effect: spatial clusters of stands). PCA ordination was performed on the structural variables in Table 1. Only traits with significance relations are reported. RaoQ: Rao index of functional divergence; CWM: community-weighted mean for quantitative traits and relative proportion of a given trait in the species assemblage for the nominal (dummy/fuzzy) and binary data.

\begin{tabular}{|c|c|c|c|c|c|}
\hline \multirow[b]{2}{*}{ Organism group } & \multirow[b]{2}{*}{ Traits/attributes } & \multicolumn{2}{|l|}{ PC1 } & \multicolumn{2}{|l|}{ PC2 } \\
\hline & & RaoQ & CWM & RaoQ & CWM \\
\hline \multirow[t]{11}{*}{ Vascular plants } & Woodiness & $-{ }^{* * *}$ & $--^{* * *}$ & ns & ns \\
\hline & Light intensity & ns & ns & ns & $+{ }^{* *}$ \\
\hline & Reproductive strategy & $-^{* * *}$ & & ns & \\
\hline & Seeds and vegetative & & $++^{* * * k}$ & & $\mathrm{~ns}$ \\
\hline & Seeds & & $--^{* * * *}$ & & ns \\
\hline & Dissemination vector & $-^{* * *}$ & & ns & \\
\hline & Anemochores & & $-^{* * * *}$ & & ns \\
\hline & Epizoochores & & $++^{* * * *}$ & & $\mathrm{~ns}$ \\
\hline & Life-strategy & ns & & ns & \\
\hline & Competitors & & $-{ }^{*}$ & & ns \\
\hline & Stress-tolerators & & $+^{\circ}$ & & $\mathrm{ns}$ \\
\hline \multirow[t]{7}{*}{ Lichens } & Growth-forms & ns & & $+*$ & \\
\hline & Foliose broad-lobed & & $+^{\circ}$ & & $+{ }^{* *}$ \\
\hline & Crustose & & $-{ }^{\circ}$ & & $-{ }^{* *}$ \\
\hline & Reproductive strategy & ns & & $+^{\circ}$ & \\
\hline & Isidiate species & & $+^{\circ}$ & & $+{ }^{* *}$ \\
\hline & Sorediate species & & ns & & $+*$ \\
\hline & Sexual reproduction & & ns & & $-^{* * *}$ \\
\hline \multirow[t]{6}{*}{ Bryophytes } & Growth-forms & ns & & ns & \\
\hline & Cushions & & $++^{* * * *}$ & & ns \\
\hline & Mats & & ns & & $-{ }^{*}$ \\
\hline & Turfs & & ns & & $+{ }^{*}$ \\
\hline & Others & & $--^{* * * *}$ & & ns \\
\hline & Light intensity & $+{ }^{*}$ & $+{ }^{* * k}$ & ns & ns \\
\hline \multirow[t]{4}{*}{ Fungi } & Host preference & $-^{* k * k}$ & & $-{ }^{* *}$ & \\
\hline & Deciduous & & $++^{* * * *}$ & & $+* *$ \\
\hline & European beech & & $--^{* * * *}$ & & $-{ }^{* * * *}$ \\
\hline & Dispersal vectors & ns & & $+^{\circ}$ & \\
\hline
\end{tabular}

+ and - symbols denote positive or negative trend, respectively.

ns, not significant, ${ }^{\circ}$ p-value $<0.1,{ }^{*}$ p-value $<0.05,{ }^{* *}$ p-values $<0.01$.

reduction in the presence of veteran trees and basal area and increase in the amount of stumps from long-unmanaged stands to intensively managed stands). The higher number of conservation-relevant species of saproxylic and epixylic organisms (fungi and epiphytes) found in the long-unmanaged stands can be interpreted as a signal of (i) recovery of favourable habitat conditions, reflecting the time since abandonment of forestry (Burrascano et al., 2008), or as an effect of (ii) higher continuity, with the persistence of suitable legacy habitats for sensitive or slow dispersing species, in stands less affected by forestry. Among the epiphytes for instance, many substrate specialists require the persistence of old beech trees because suitable microhabitats, such as rough bark and rot holes, only develop at high tree age, often on slow-growing and suppressed trees (Fritz and Brunet, 2010).

Nevertheless, we found a contrasting pattern for the vascular plants. We were somewhat surprised to measure higher richness of vascular plants listed as old-growth indicators (sensu Hermy and Honnay, 1999; Schmidt et al., 2014) in the managed stands, but similar patterns were found also by Boch et al. (2013), who studied vascular plants in 1500 plots in European beech forests, comprising several management types and stand ages. They found a higher richness of typical herbaceous forest species in the managed compared to unmanaged stands, likely favoured by higher availability and heterogeneity of resources (such as light, nutrients) with moderate disturbance by management. Thus, environmental conditions in production forests may not be unfavourable for plants identified as old-growth indicators. In this context it is worth emphasizing that the old-growth indicator plants were identified based on studies comparing managed forests with various continuity levels, but with generally low naturalness in European lowlands. Hence, they may indeed be very suitable for identifying forest characterized by high forest connectivity and continuity, as for our study area, but not forests with low impact of forestry. In contrast, old-growth indicators of lichens, bryophytes and fungi have generally been selected to indicate forests with low management impact (e.g., Nitare, 2000; Christensen et al., 2005), and hence were expected to be more responsive to changes in management-related environmental variables. However, studies of biodiversity responses to forest management intensity in Europe need also to acknowledge that the whole system is strongly human-modified, even in the case of long-unmanaged stands or remnant old-growth forests. In such systems, extinction debts and credits may create odd biodiversity patterns, deviating from patterns in forest systems subject to more recent degradation and management. Furthermore, because most of the unmanaged forests were formerly managed to some degree, they probably have not yet reached natural levels of habitat variation (e.g. concerning dead wood and veteran trees) (Sabatini et al., 2018). More generally, structure, processes and natural disturbance events which may increase habitat heterogeneity and the resource availability for several species groups in old-growth forests, may still be not evident even in many long-unmanaged forests (Burrascano et al., 2017; Schall et al., 2018).

Another important issue is spatial scale. Drivers of forest biodiversity may act at different spatial scales depending on forest maturity, management regime and the organism group considered, leading to very different richness patterns at different scales (e.g., Standovár et al., 2006; Burrascano et al., 2018). Recently, Schall et al. (2018) showed how differently grained forest management systems affect the biodiversity of multiple taxa across spatial scales, finding that a mosaic of different age-classes is more important for regional biodiversity than high within-stand heterogeneity. In fact, they measured higher regional gamma-diversity in even-aged forests compared to uneven-aged forests driven by between-stand beta-diversity and not by local alpha-diversity. This indicates that only focusing on stand-level species richness (alphadiversity) may mask patterns of diversity occurring at different spatial scales. In this context it is worth emphasizing that our sampling of epiphytes and vascular plants was optimized to capture stand-level species richness as well as possible, rather than to follow a random protocol or a full inventory as implemented for fungi and breeding birds. While this was done to control for the highly patchy nature of plant communities in natural forests (cf. Kaufmann et al., 2017), and of conservation-relevant epiphytes in managed forests (Fritz, 2009), this may boost the measured species richness in our studies, compared to those using a completely random sampling.

Although our study was mainly focused on the responses to changes in management-related environmental variables along PC1, some of the species richness responses to structural factors expressed by PC2 are also worth discussing. For instance, the positive response of lichen species richness, including red-listed species, suggests that this group can be favoured by the heterogeneous conditions in canopy cover generated through stand clearings, as also found in previous studies (e.g., Giordani et al., 2012; Ódor et al., 2014). Finally, the negative trend of fungal richness along PC2 is most likely related to higher productivity and the resulting higher dead wood amounts in the denser stands on flat ground with less acidic soils. We hypothesize that the habitat suitability (i.e., presence of available substrate) is probably the main driver which promotes richer wood-inhabiting fungi assemblages in our study system. However, other interrelated factors, like soil and wood moisture and $\mathrm{pH}$, may also play a role in regulating the activity and richness of wood decaying organisms (cf. Pouska et al., 2016; Bardelli et al., 2018).

\subsection{Functional diversity}

The functional approach partly confirmed the expectation that functional diversity decreases with changes in management-related 
environmental variables from long unmanaged to managed stands, but the results were complex. The clearest results were found for assemblages of vascular plants with a higher occurrence of herb species (e.g., Šebesta et al., 2017) and species with generalist dispersal strategies from long unmanaged to managed stands. For the other groups, re sponses were more varied, but consistent with a loss of specialization and progressive banalization of species assemblages. We measured a decline in resource specialists wood inhabiting fungi (i.e., specialized saproxylic fungi confined to European beech wood) likely linked to a decrease in substrate availability (Nordén et al., 2013). Similarly, the predominance of bryophytes with higher light requirements and cushion shape growth has earlier been linked with disturbance and with a reduction in habitat continuity (such as canopy cover) (During, 1979; Brunet et al., 2010).

However, the loss of specialization and the increase in more generalist strategies do not necessarily imply a reduction in functional diversity. Indeed, previous studies found that disturbance events even due to forestry activities may promote more diverse species assemblages. For instance, a partially or completely removed forest canopy (as a result of natural disturbance or management) compared with undisturbed forest patches, was found to promote the diversity of several functional groups, including pollinators and arthropod herbivores, likely driven by increased diversity and abundance of plants (Campbell and Donato, 2014). In our study, gaps in the canopy cover favoured especially light demanding herb species, as well as lichens with vegetative reproduction strategies and more diverse growth forms (Ellis, 2012).

As also demonstrated by the examples above, the functional approach may effectively complement effective diversity surveys (Blüthgen et al., 2016). In fact, species assemblages may change functionally without significant changes in species richness or in the number of conservation relevant species. In our study, this was the case for bryophytes, for which the change in the dominance of growth forms was not reflected in a variation of species richness. Finally, the gen erally weak functional response of birds may reflect their dependence on forest conditions at a wider landscape scale (Aubin et al., 2013) than at stand level, especially in contexts of high forest continuity and connectivity. Stronger changes of animal communities have been evi denced especially with more marked habitat changes, like the conver sion of forests into open grasslands, than for gradual variation of forest structure and management (Blüthgen et al., 2016).

Overall, the clearest functional signal related to forest management and structure was found for vascular plants. This may reflect that this group is better understood and described in terms of functional traits (Cornelissen et al., 2003), while trait based approaches remain less developed for the other organism groups considered. However, despite the informative potential of the functional approach, at present the limited number of measured and ecologically understood traits for the less studied organism groups (Paillet et al., 2010) (particularly the bryophytes in our case) makes this approach still scarcely informative for conservation purposes compared to the use of lists of conservation relevant species.

\section{Conclusions}

Our study confirms the findings from several previous studies that forest biodiversity and its response to changes in management related environmental variables is complex. Based on our results the richness of conservation relevant species of epiphytes and saproxylic fungi appear to be suited as indicator of management impact in forests, while the richness of vascular plants, even so called old growth indicators, are more indicative of disturbances of natural or anthropogenic nature.

This reflects the well known notion, that the mechanisms that shape patterns of diversity are not identical among species groups. Therefore a multi taxon framework is increasingly recommended for guiding conservation action (e.g., Flensted et al., 2016; Schall et al., 2018).
However, identifying species across many relevant taxonomic groups is time and resource consuming, and often impractical in broad scale monitoring and research, while rapid assessment methods are needed for practical conservation. In this context, the identification and validation of suitable indicators of overall biodiversity and underlying ecosystem processes is key to ensure conservation that is both ecologically and resource efficient. The use of a functional approach has considerable potential in this context, if suitable recognisable and re sponsive traits can be identified (e.g., Aragón et al., 2016). For reaching this goal a preliminary selection and subsequent testing of responsive traits is required for each species group. Indeed, functional approaches depend on the compilation and evaluation of traits with documented relevance, which are only partially available, and mainly for more well studied groups. We hope future studies will improve the situation, e.g., for fungi, lichens and bryophytes, in order to identify the best suited traits which may help in effective and rapid biodiversity assessments.

\section{Author contributions}

CL and JHC formulated the specific research hypotheses and designed the analytical setup, with input from HHB, AC, IG and JN. The overall project was formulated and coordinated by JHC, HHB, APT and $\mathrm{CR}$, who also designed the field sampling protocols, with input from IG and ÖF, who collected data on ground vegetation and epiphytes respectively. CL processed and analyzed the data with help from DD and FF. CL wrote the manuscript in close collaboration with JHC, in corporating critical feedback from all authors, which helped shape the manuscript.

\section{Acknowledgments}

Mie Siezing Hansen, Tommy Knutsson, Troels Eske Ortvad, are thanked for collecting part of the data used in this paper, Bjørn Hermansen is thanked for help with the GIS work while Jan Erik Løvgren and Jens Bjerregaard Christensen are thanked for providing advice on stand selection in Gribskov. Stefan Ekman (Uppsala) is thanked for the identification of samples of Bacidina, while Thomas Læssøe (Copenhagen) and Leif Örstadius (Kristiansstad) helped with the identification of some fungal collections.

Péter Ódor (Budapest) kindly provided information and sources on bryophytes traits.

\section{Funding}

This work was supported by the 15. June Foundation, and the Danish National Research Foundation that funded the Center for Macroecology, Evolution and Climate (grant n. DNRF96)

\section{Appendix A. Supplementary material}

Supplementary data to this article can be found online at https:// doi.org/10.1016/j.foreco.2018.09.057.

\section{References}

Aragón, G., Belinchón, R., Martínez, I., Prieto, M., 2016. A survey method for assessing the richness of epiphytic lichens using growth forms. Ecol. Indic. 62, 101-105. https://doi.org/10.1016/j.ecolind.2015.11.034.

Aubin, I., Venier, L., Pearce, J., Moretti, M., 2013. Can a trait-based multi-taxa approach improve our assessment of forest management impact on biodiversity? Biodivers. Conserv. 22, 2957-2975. https://doi.org/10.1007/s10531-013-0565-6.

Bate, L.J., Torgersen, T.R., Wisdom, M.J., Garton, E.O., 2009. Biased estimation of forest $\log$ characteristics using intersect diameters. For. Ecol. Manage. 258, 635-640. Bardelli, T., Ascher-Jenull, J., Burkia Stocker, E., Fornasier, F., Arfaioli, P., Fravolini, G., Alves Medeiros, L.R., Egli, M., Pietramellara, G., Insam, H., Gómez-Brandón, M., 2018. Impact of slope exposure on chemical and microbiological properties of Norway spruce deadwood and underlying soil during early stages of decomposition in the Italian Alps. Catena 167, 100-115. https://doi.org/10.1016/j.catena.2018.04. 031. 
Bässler, C., Cadotte, M.W., Beudert, B., Heibl, C., Blaschke, M., Bradtka, J.H., Langbehn, T., Werth, S., Müller, J., 2016a. Contrasting patterns of lichen functional diversity and species richness across an elevation gradient. Ecography (Cop.) 39, 689-698. https://doi.org/10.1111/ecog.01789.

Bässler, C., Müller, J., Cadotte, M.W., Heibl, C., Bradtka, J.H., Thorn, S., Halbwachs, H., 2016b. Functional response of lignicolous fungal guilds to bark beetle deforestation. Ecol. Indic. 65, 149-160.

Bates, D., Maechler, M., Bolker, B., Walker, S., 2015. Fitting linear mixed-effects models using lme4. J. Stat. Softw. 67, 1-48.

Bauhus, J., Puettmann, K., Messier, C., 2009. Silviculture for old-growth attributes. For. Ecol. Manage. 258, 525-537.

Bengtsson, J., Nilsson, S.G., Franc, A., Menozzi, P., 2000. Biodiversity, disturbances, ecosystem function and management of European forests. For. Ecol. Manage. 132,

39-50.

Bibby, C.J., Burgess, N.D., Hill, D.A., Mustoe, S., 2000. Bird Census Techniques, second ed. Academic Press.

Blüthgen, N., Simons, N.K., Jung, K., Prati, D., Renner, S.C., Boch, S., Fischer, M., Hölzel, N., Klaus, V.H., Kleinebecker, T., Tschapka, M., Weisser, W.W., Gossner, M.M., 2016. Land use imperils plant and animal community stability through changes in asynchrony rather than diversity. Nat. Commun. 7. https://doi.org/10.1038/ ncomms10697.

Bocci, G., 2015. TR8: an R package for easily retrieving plant species traits. Methods Ecol. Evol. 6, 347-350. https://doi.org/10.1111/2041-210X.12327.

Boch, S., Prati, D., Müller, J., Socher, S., Baumbach, H., Buscot, F., Gockel, S., Hemp, A., Hessenmöller, D., Kalko, E.K.V., Linsenmair, K.E., Pfeiffer, S., Pommer, U., Schöning, I., Schulze, E.D., Seilwinder, C., Weisser, W.W., Wells, K., Fischer, M., 2013. High plant species richness indicates management-related disturbances rather than the conservation status of forests. Basic Appl. Ecol. 14, 496-505. https://doi.org/10. 1016/j.baae.2013.06.001

Bolker, B.M., Brooks, M.E., Clark, C.J., Geange, S.W., Poulsen, J.R., Stevens, M.H., White, J.S., 2009. Generalized linear mixed models: a practical guide for ecology and evo-lution. Trends Ecol. Evol. 24, 127-135.

Brunet, J., Fritz, Ö., Richnau, G., 2010. Biodiversity in European beech forests - a review with recommendations for sustainable forest management. Ecol. Bull. 53, 77-94. Burrascano, S., Lombardi, F., Marchetti, M., 2008. Old-growth forest structure and deadwood: Are they indicators of plant species composition? A case study from central Italy. Plant Biosyst. 142, 313-323.

Burrascano, S., Keeton, W.S., Sabatini, F.M., Blasi, C., 2013. Commonality and variability in the structural attributes of moist temperate old-growth forests: a global review. For. Ecol. Manage. 291, 458-479.

Burrascano, S., Ripullone, F., Bernardo, L., Borghetti, M., Carli, E., Colangelo, M., Gangale, C., Gargano, D., Gentilesca, T., Luzzi, G., Passalacqua, N., Pelle, L., Rivelli, A.R., Sabatini, F.M., Schettino, A., Siclari, A., Uzunov, D., Blasi, C., 2017. It's a long way to the top: plant species diversity in the transition from managed to old-growth forests. J. Veg. Sci. 98-109. https://doi.org/10.1111/jvs.12588.

Burrascano, S., Antonini, G., Sitzia, T., Janssen, F.G.P., Blasi, C., Nascimbene, A.M.P.J., 2018. Congruence across taxa and spatial scales: are we asking too much of species data? Glob. Ecol. Biogeogr. 980-990. https://doi.org/10.1111/geb.12766.

Campbell, J.L., Donato, D.C., 2014. Trait- based approaches to linking vegetation and food webs in early-seral forests of the Pacific Northwest. For. Ecol. Manage. 324, $172-178$.

Chaudhary, A., Burivalova, Z., Koh, L.P., Hellweg, S., 2016. Impact of forest management on species richness: global meta-analysis and economic trade-offs. Sci. Rep. 6, 1-10. https://doi.org/10.1038/srep23954.

Chiarucci, A., Bacaro, G., Scheiner, S.M., 2011. Old and new challenges in using species diversity for assessing biodiversity. Philos. Trans. R. Soc. 366, 2426-2437. Christensen, M., Heilmann-Clausen, J., 2009. Forest biodiversity gradients and the human impact in Annapurna Conservation Area. Nepal. Biodivers. Conserv. 18, 2205-2221.

Christensen, M., Heilmann-Clausen, J., Walleyn, R., Adamcik, S., 2005. Wood-inhabiting fungi as indicators of nature value in European beech forests. In: EFI Proc. No. 51 Monitoring and Indicators of Forest Biodiversity in Europe - From Ideas to Operationality, pp. 229.

Colwell, R.K., Coddington, J.A., 1994. Estimating terrestrial biodiversity through extrapolation. Philos. Trans. R. Soc. 345, 101-118.

Cornelissen, J.H.C., Lavorel, S., Garnier, E., Díaz, S., Buchmann, N., Gurvich, D.E., Reich, P.B., Ter Steege, H., Morgan, H.D., Van Der Heijden, M.G., Pausas, J.G., Poorter, H., 2003. A handbook of protocols for standardised and easy measurement of plant functional traits worldwide. Aust. J. Bot. 51, 335-380. https://doi.org/10.1071/ BT02124.

Curzon, M.T., D’Amato, A.W., Fraver, S., Palik, B.J., Bottero, A., Foster, J.R., Gleason, K.E., 2017. Harvesting influences functional identity and diversity over time in forests of the northeastern U.S.A. For. Ecol. Manage. 400, 93-99. https://doi.org/10. 1016/j.foreco.2017.05.056.

DOF, 2018. Danish Ornithological Society, Danmarks Fugle. https://dofbasen.dk/ART/ (accessed in January 2018).

Dolman, P.M., Panter, C.J., Mossman, H.L., 2012. The biodiversity audit approach challenges regional priorities and identifies a mismatch in conservation. J. Appl. Ecol. 49, 986-997. https://doi.org/10.1111/j.1365-2664.2012.02174.x.

Dray, S., Dufour, A.-B., 2007. The ade4 package: Implementing the duality diagram for ecologists. J. Stat. Softw. 22, 1-20.

During, H.J., 1979. Life strategies of bryophytes: a preliminary review. Lindbergia 5, 2-18.

During, H.J., 1992. Ecological classification of bryophytes and lichens. In: Bates, J. Farmer, A. (Eds.), Bryophytes and lichens in a changing environment. Clarendon Press, Oxford, pp. 1-31.

Ellenberg, H., 1974. Zeigerwerte der Gefaßpflanzen Mitteleuropas. Gottingen, Erich
Goltze GmbH, Co KG, pp. 97.

Ellenberg, H., Weber, H.E., Düll, R., Wirth, V., Werner, W., Paulissen, D., 1991. Zeigerwerte von Pflanzen in Mitteleuropa (Scripta Geobotanica 18). Verlag E, Goltze KG, Göttingen

Ellis, C.J., 2012. Lichen epiphyte diversity: a species, community and trait-based review. Perspect. Plant Ecol. Evol. Syst. 14, 131-152. https://doi.org/10.1016/j.ppees.2011. 10.001 .

Emborg, J., Christensen, M., Heilmann-Clausen, J., 2000. The structural dynamics of Suserup Skov, a near-natural temperate deciduous forest in Denmark. For. Ecol. Manage. 126, 173-189.

Fitter, A.H., Peat, H.J., 1994. The ecological flora database. J. Ecol. 82, 415-425. http:// www.ecoflora.co.uk.

Flensted, K.K., Bruun, H.H., Ejrnaes, R., Eskildsen, A., Thomsen, P.F., Heilmann-Clausen, J., 2016. Red-listed species and forest continuity - a multi-taxon approach to conservation in temperate forests. For. Ecol. Manage. 378, 144-159. https://doi.org/10. $1016 /$ j.foreco.2016.07.029.

Fritz, Ö., 2009. Ecology and conservation of bryophytes and lichens on Fagus sylvatica. Doctoral Thesis No. 2009:10. Faculty of Forest Sciences, SLU.

Fritz, Ö., Brunet, J., 2010. Epiphytic bryophytes and lichens in Swedish beech forests effects of forest history and habitat quality. Ecol. Bull. 53, 95-107.

Fritz, Ö., 2011. Lunglav minskar och bokfjädermossa ökar i Hallands bokskogar. Svensk Bot. Tidskr. 105, 163-177.

Garnier, E., Cortez, J., Billes, G., Navas, M.L., Roumet, C., Debussche, M., Laurent, G., Blanchard, A., Aubry, D., Bellmann, A., Neill, C., Toussaint, J.P., 2004. Plant functional markers capture ecosystem properties during secondary succession. Ecology 85, 2630-2637.

Garnier, E., Navas, M.-L., Grigulis, K., 2016. Plant Functional Diversity: Organism Traits, Community Structure, and Ecosystem Properties. Oxford University Press.

Giordani, P., Brunialti, G., Bacaro, G., Nascimbene, J., 2012. Functional traits of epiphytic lichens as potential indicators of environmental conditions in forest ecosystems. Ecol. Indic. 18, 413-420. https://doi.org/10.1016/j.ecolind.2011.12.006.

Gossner, M.M., Schall, P., Ammer, C., Ammer, U., Engel, K., Schubert, H., Simon, U., Utschick, H., Weisser, W.W., 2014. Forest management intensity measures as alternative to stand properties for quantifying effects on biodiversity. Ecosphere 5, art113. https://doi.org/10.1890/ES14-00177.1.

Gotelli, N., Graves, G.R., Rahbek, C., 2010. Macroecological signals of species interactions in the Danish avifauna. Proc. Natl. Acad. Sci. 107, 5030-5035. https://doi.org/10.

1073/pnas.0914089107.

Gotelli, N., Colwell, R.K., 2001. Quantifying biodiversity: procedures and pitfalls in the measurement and comparison of species richness. Ecol. Lett. 4, 379-391. https://doi. org $/ 10.1046 / \mathrm{j} .1461-0248.2001 .00230 . x$.

Graae, B.J., Buchwald, E., 1997. Særligt beskyttet naturskov - Lokaliteter i Statsskovene, vol. 1 Skov. og Naturstyrelsen.

Graae, B.J., Sunde, P.B., 2000. The impact of forest continuity and management on forest floor vegetation evaluated by species traits. Ecography 23, 720-731. https://doi.org/

10.1111/j.1600-0587.2000.tb00315.x.

Grime, J.P., 2001. Plant Strategies, Vegetation Processes and Ecosystem Properties, second ed. Wiley.

Hallingbäck, T., Aronsson, G. (eds.), 1998. Ekologisk katalog över storsvampar och myxomyceter. [Macrofungi and myxomycetes of Sweden and their ecology.] ArtDatabanken, SLU, Uppsala. 2nd revised and extended printing.

Halme, P., Holec, J., Heilmann-Clausen, J., 2017. The history and future of fungi as biodiversity surrogates in forests. Fungal Ecol. 27, 193-201.

Heilmann-Clausen, J., Aude, E., van Dort, K., Christensen, M., Piltaver, A., Veerkamp, M., Walleyn, R., Siller, I., Standovár, T., Òdor, P., 2014. Communities of wood-inhabiting bryophytes and fungi on dead beech logs in Europe - reflecting substrate quality or shaped by climate and forest conditions? J. Biogeogr. 41, 2269-2282. https://doi. org/10.1111/jbi.12388.

Hermy, M., Honnay, O., 1999. An ecological comparison between ancient and other forest plant species of Europe, and the implications for forest conservation. Biol. Conserv. 91, 9-22.

Hill, M.O., Preston, C.D., Bosanquet, S.D.S., Roy, D.B., 2007. BRYOATT: Attributes of British and Irish Bryophytes.

Julve, P., 1998. Baseflor. Index botanique, écologique et chorologique de la flore de France. Version: 26 November 2014. http://perso.wanadoo.fr/philippe.julve/ catminat.htm.

Kahl, T., Bauhus, J., 2014. An index of forest management intensity based on assessment of harvested tree volume, tree species composition and dead wood origin. Nat. Conserv. 7, 15-27. https://doi.org/10.3897/natureconservation.7.7281.

Kassambara, A., Mundt, F., 2016. Factoextra: extract and visualize the results of multivariate data analyses. R Package. version 1.

Kaufmann, S., Hauck, M., Leuschner, C., 2017. Comparing the plant diversity of paired beech primeval and production forests: management reduces cryptogam, but not vascular plant species richness. For. Ecol. Manage. 400, 58-67. https://doi.org/10. 1016/j.foreco.2017.05.043

Kleyer, M., Bekker, R.M., Knevel, I.C., Bakker, J.P., Thompson, K., Sonnenschein, M., Poschlod, P., Van Groenendael, J.M., Klimeš, L., Klimešová, J., Klotz, S., Rusch, G.M., Hermy, M., Adriaens, D., Boedeltje, G., Bossuyt, B., Dannemann, A., Endels, P., Götzenberger, L., Hodgson, J.G., Jackel, A.K., Kühn, I., Kunzmann, D., Ozinga, W.A., Römermann, C., Stadler, M., Schlegelmilch, J., Steendam, H.J., Tackenberg, O., Wilmann, B., Cornelissen, J.H.C., Eriksson, O., Garnier, E., Peco, B., 2008. The LEDA Traitbase: a database of life-history traits of the Northwest European flora. J. Ecol. 96, 1266-1274. https://doi.org/10.1111/j.1365-2745.2008.01430.x.

Klotz, S., Kühn, I., Durka,W. (Eds), 2002. BIOLFLOR - Eine Datenbank zu biologischökologischen Merkmalen zur Flora von Deutschland. Schriftenreihe für Vegetationskunde 38, 1-333. (Bunde- samt für. Bonn, Bundesamt für Naturschutz). 
Kraus, D., Krumm, F. (Eds.), 2013. Integrative Approaches as an Opportunity for the Conservation of Forest Biodiversity. European Forest Institute, Freiburg, Germany, pp. 284.

Knudsen, H., Vesterholt, J., 2012. Funga Nordica. Agaricoid, Boletoid, Clavarioid, Cyphelloid and Gastroid Genera. Nordsvamp, Denmark.

Laliberté, E., Legendre, P., Shipley, B., 2015. FD: measuring functional diversity from multiple traits, and other tools for functional ecology. R package version 1.0-12. Lepš, J. de Bello, F., Lavorel, S., Berman, S., 2006. Quantifying and interpreting functional diversity of natural communities: practical considerations matter. Preslia 78 481-501.

Mason, N.W.H., Mouillot, D., Lee, W.G., Wilson, J.B., 2005. Functional richness, functional evenness and functional divergence: the primary components of functional diversity. Oikos 111, 112-118. https://doi.org/10.1111/j.0030-1299.2005.13886.x.

Nascimbene, J., Marini, L., 2015. Epiphytic lichen diversity along elevational gradients: biological traits reveal a complex response to water and energy. J. Biogeogr. 1222-1232. https://doi.org/10.1111/jbi.12493.

Nascimbene, J., Mayrhofer, H., Dainese, M., Bilovitz, P.O., 2017. Assembly patterns of soil-dwelling lichens after glacier retreat in the European Alps. J. Biogeogr. 44, 1393-1404. https://doi.org/10.1111/jbi.12970.

Newbold, T., Scharlemann, J.P.W., Butchart, S.H.M., Sekercioglu, C..H., Alkemade, R., Booth, H., Purves, D.W., 2012. Ecological traits affect the response of tropical forest bird species to land-use intensity. Proc. R. Soc. B 280, 1-8. https://doi.org/10.1098/ rspb.2012.2131.

Nimis, P.L., Martellos, S., 2017. ITALIC - The Information System on Italian Lichens. Version 5.0. University of Trieste, Dept. of Biology.

Nitare, J., 2000. Indicator Species for Assessing the Nature Conservation Value of Woodland Sites: A Flora of Selected Cryptogams (in Swedish). Skogstyrelsen, Karlshamn, pp. 384

Nordén, J., Penttilä, R., Siitonen, J., Tomppo, E., Ovaskainen, O., 2013. Specialist species of wood-inhabiting fungi struggle while generalists thrive in fragmented boreal forests. J. Ecol. 101, 701-712.

Nordén, B., Dahlberg, A., Brandrud, T.E., Fritz, Ö., Ejrnæs, R., Ovaskainen, O., 2014. Effects of ecological continuity on species richness and composition in forests and woodlands: a review. Écoscience 21, 34-45. https://doi.org/10.2980/21-1-3667. Ódor, P., Király, I., Tinya, F., Bortignon, F., Nascimbene, J., 2014. Patterns and drivers of species composition of epiphytic bryophytes and lichens in managed temperate forests. For. Ecol. Manage. 321, 42-51. https://doi.org/10.1016/j.foreco.2014.01.035.

Overballe-Petersen, M.V., Nielsen, A.B., Hannon, G.E., Halsall, K., Bradshaw, R.H.W. 2013. Long-term forest dynamics at Gribskov, eastern Denmark with early-Holocene evidence for thermophilous broadleaved tree species. Holocene 23, 243-254.

Paillet, Y., Bergès, L., Hjaltén, J., Ódor, P., Avon, C., Bernhardt-Römermann, M., Bijlsma, R.J., De Bruyn, L., Fuhr, M., Grandin, U., Kanka, R., Lundin, L., Luque, S., Magura, T., Matesanz, S., Mészaros, I., Sebastià, M.T., Schmidt, W., Standovár, T., Tothmérész, B., Uotila, A., Valladares, F., Vellak, K., Virtanen, R., 2010. Biodiversity differences between managed and unmanaged forests: meta-analysis of species richness in Europe. Conserv. Biol. 24, 101-112. https://doi.org/10.1111/j.1523-1739.2009.01399.x.

Pausas, J.G., Verdú, M., 2010. The jungle of methods for evaluating phenotypic and phylogenetic structure of communities. Bioscience 60, 614-625. https://doi.org/10.

1525/bio.2010.60.8.7.

Pouska, V., Macek, P., Zíbarová, L., 2016. The relation of fungal communities to wood microclimate in a mountain spruce forest. Fungal Ecol. 21, 1-9.

Core Team, R., 2017. R: A Language and Environment for Statistical Computing. R Foundation for Statistical Computing, Vienna.

Roberts, M.R., 2004. Response of the herbaceous layer to natural disturbance in North American forests. Can. J. Bot. 82, 1273-1283.

Rune, F., 2009. Gribskov - Skovens udvikling og kulturhistorie fra istid til nutid. Forlaget Esrum Sø, Fredensborg, pp. 357.
Ricotta, C., Moretti, M., 2011. CWM and Rao's quadratic diversity: a unified framework for functional ecology. Oecologia 167, 181-188. https://doi.org/10.1007/ s00442-011-1965-5.

Ryvarden, L., Melo, I., Niemelä, T., 2014. Poroid fungi of Europe. Synopsis Fungorum, vol 31 Fungiflora, Oslo.

Sabatini, F.M., Burrascano, S., Azzella, M.M., Barbati, A., De Paulis, S., Di Santo, D. Facioni, L., Giuliarelli, D., Lombardi, F., Maggi, O., Mattioli, W., Parisi, F., Persiani, A., Ravera, S., Blasi, C., 2016. One taxon does not fit all: Herb-layer diversity and stand structural complexity are weak predictors of biodiversity in Fagus sylvatica forests. Ecol. Indic. 69, 126-137. https://doi.org/10.1016/j.ecolind.2016.04.012.

Sabatini, F., Burrascano, S., Keeton, W.S., Levers, C., Lindner, M., Pötzschner, F., Verkerk, P.J., Bauhus, J., Buchwald, E., Chaskovsky, O., Debaive, N., Horváth, F., Garbarino, M., Grigoriadis, N., Lombardi, F., Duarte, I.M., Meyer, P., Midteng, R., Mikac, S., Mikoláš, M., Motta, R., Mozgeris, G., Nunes, L., Panayotov, M., Ódor, P., Ruete, A. Simovski, B., Stillhard, J., Svoboda, M., Szwagrzyk, J., Tikkanen, O.-P., Volosyanchuk, R., Vrska, T., Zlatanov, T., Kuemmerle, T., 2018. Where are Europe's last primary forests? Divers. Distrib. 1-14. https://doi.org/10.1111/ddi.12778.

Schall, P., Gossner, M.M., Heinrichs, S., Fischer, M., Boch, S., Prati, D., Jung, K., Baumgartner, V., Blaser, S., Böhm, S., Buscot, F., Daniel, R., Goldmann, K., Kaiser, K., Kahl, T., Lange, M., Müller, J., Overmann, J., Renner, S.C., Schulze, E.D., Sikorski, J. Tschapka, M., Türke, M., Weisser, W.W., Wemheuer, B., Wubet, T., Ammer, C., 2018. The impact of even-aged and uneven-aged forest management on regional biodiversity of multiple taxa in European beech forests. J. Appl. Ecol. 55, 267-278. https://doi.org/10.1111/1365-2664.12950.

Schmidt, M., Mölder, A., Schönfelder, E., Engel, F., Schmiedel, I., Culmsee, H., 2014. Determining ancient woodland indicator plants for practical use: a new approach developed in northwest Germany. For. Ecol. Manage. 330, 228-239. https://doi.org/ 10.1016/j.foreco.2014.06.043.

Šebesta, J., Maděra, P., Řepka, R., Matula, R., 2017. Comparison of vascular plant diversity and species composition of coppice and high beech forest in the Banat region, Romania. Folia Geobot. 52, 33-43. https://doi.org/10.1007/s12224-016-9279-3.

Simmel, J., Bässler, C., Poschlod, P., 2017. Ellenberg indicator values for macromycetes a methodological approach and first applications. Fungal Ecol. 27, 202-212. https:// doi.org/10.1016/j.funeco.2016.09.004.

Sitzia, T., Campagnaro, T., Dainese, M., Cassol, M., Cortivo, M., Gatti, E., Padovan, F., Sommacal, M., Nascimbene, J., 2017. Contrasting multi-taxa diversity patterns between abandoned and non-intensively managed forests in the southern Dolomites. iForest - Biogeosci. For. 10, 845-850. https://doi.org/10.3832/ifor2181-010.

Standovár, T., Ódor, P., Aszalós, R., Gálhidy, L., 2006. Sensitivity of ground layer vegetation diversity descriptors in indicating forest naturalness. Commun. Ecol. 7 , 199-209. https://doi.org/10.1556/ComEc.7.2006.2.7.

Svensson, L., Mullarney, K., Zetterstrom, D., Grant, P.J., Christie, D.A., 2010. Collins Bird Guide: The Most Complete Guide to the Birds of Britain and Europe, second ed. Collins.

Thor, G., Arvidsson, L. (red.)., 1999. Rödlistade lavar i Sverige - Artfakta. ArtDatabanken, SLU, Uppsala.

Violle, C., Navas, M., Vile, D., Kazakou, E., Fortunel, C., Hummel, I., Garnier, E., 2007. Let the concept of trait be functional!. Oikos 1-11. https://doi.org/10.1111/j.2007. 0030-1299.15559.x.

Wind, P., Pihl, S. (Eds.), 2004. The Danish Red List. - The National Environmental Research Institute, Aarhus University - redlist.dmu.dk (updated April 2010).

Winter, S., Möller, G.C., 2008. Microhabitats in lowland beech forests as monitoring tool for nature conservation. For. Ecol. Manage. 255, 1251-1261. https://doi.org/10. 1016/j.foreco.2007.10.029.

Wirth, V., 2010. Ökologische Zeigerwerte von Flechten - Erweiterte und Aktualisierte Fassung. Herzogia 23, 229-248. 